\title{
Cellular Interplay as a Consequence of Inflammatory Signals Leading to Liver Fibrosis Development
}

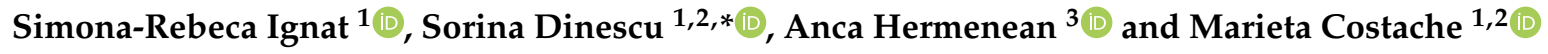 \\ 1 Department of Biochemistry and Molecular Biology, University of Bucharest, 050095 Bucharest, Romania; \\ simona.ignat@unibuc.ro (S.-R.I.); marieta.costache@bio.unibuc.ro (M.C.) \\ 2 Research Institute of the University of Bucharest, 050663 Bucharest, Romania \\ 3 Institute of Life Sciences, Vasile Goldis Western University of Arad, 310414 Arad, Romania; \\ anca.hermenean@gmail.com \\ * Correspondence: sorina.dinescu@bio.unibuc.ro; Tel.: +40-213-181-575
}

Academic Editor: Ralf Weiskirchen

Received: 6 January 2020; Accepted: 15 February 2020; Published: 18 February 2020

\begin{abstract}
Inflammation has been known to be an important driver of fibrogenesis in the liver and onset of hepatic fibrosis. It starts off as a process meant to protect the liver from further damage, but it can become the main promoter of liver fibrosis. There are many inflammation-related pathways activated during liver fibrosis that lead to hepatic stellate cells (HSCs) activation and collagen-deposition in the liver. Such events are mostly modulated upstream of HSCs and involve signals from hepatocytes and innate immune cells. One particular event is represented by cell death during liver injury that generates multiple inflammatory signals that further trigger sterile inflammation and enhancement of inflammatory response. The assembly of inflammasome that responds to danger-associated molecular patterns (DAMPs) stimulates the release of pro-inflammatory cytokines and at the same time, initiates programmed cell death called pyroptosis. This review focuses on cellular and molecular mechanisms responsible for initiation and progress of inflammation in the liver.
\end{abstract}

Keywords: liver inflammation; liver fibrosis; sterile inflammation; inflammasome; DAMPs

\section{Introduction}

Liver fibrosis affects liver structure with extracellular matrix (ECM) deposition and scar tissue formation, an important hallmark. Among the causes leading to liver fibrosis are viral hepatitis $(\mathrm{B}, \mathrm{C})$, excessive alcohol consumption, non-alcoholic steatohepatitis (NASH), metabolic diseases, autoimmune diseases, congenital syndromes. From all types of liver injury, liver fibrosis is a condition that could be reversed and liver integrity reestablished [1]. However, if the fibrous tissue accumulation affects too much liver function, liver fibrosis can turn into cirrhosis or hepatocellular carcinoma, both irreversible stages of liver disease. For this reason, it is important to know the events that lead to liver fibrosis onset, with special focus on one of the key cellular players in liver fibrosis, hepatic stellate cells (HSCs), which are activated by all the inflammation-related molecular changes in the liver [2,3].

Inflammation represents an important factor in chronic or acute liver disorder progress. It starts off as a process meant to protect the liver from further damage, but it can become the main promoter of liver fibrosis [3-5]. A series of events are set in motion by inflammation leading up to HSCs activation and collagen-deposition in the liver [5]. Such events are modulated upstream of HSCs and involve signals from hepatocytes and innate immune cells [6]. Almost every change that occurs in liver fibrosis affects the behavior of HSCs, supporting their transdifferentiation towards a myofibroblastic phenotype. In the normal liver, HSCs make up to $15 \%$ of the total liver cells and are located in the space of Disse. Following their activation, the quiescent vitamin A-storing HSCs turn into highly proliferative, fibrogenic and contractile myofibroblasts responsible for altered ECM-deposition (Figure 1) [5,7-10]. 


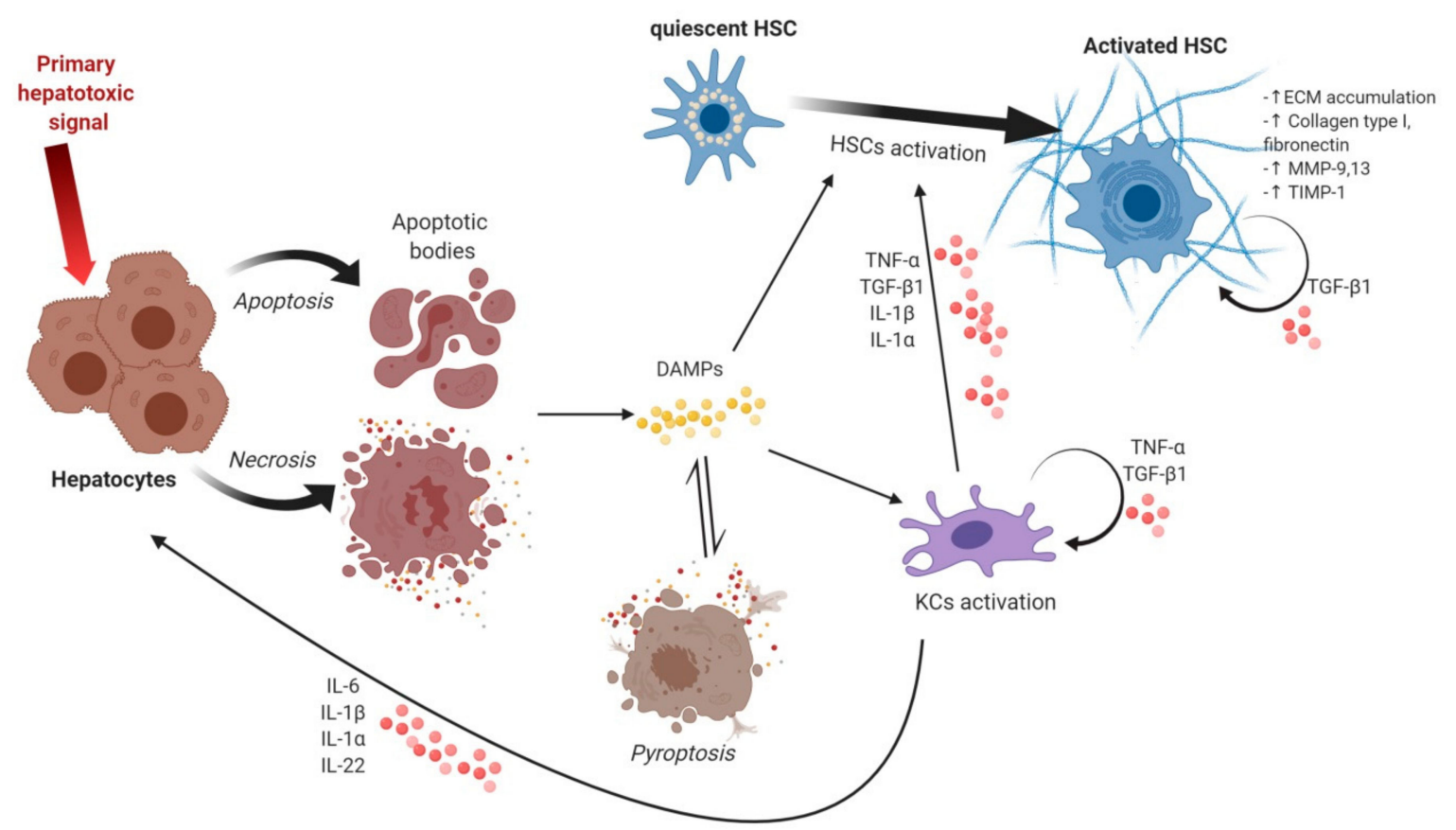

Figure 1. Events leading to hepatic stellate cells (HSCs) activation and accumulation of extracellular matrix. The hepatotoxic signal is the first to induce cellular death in hepatocytes by either apoptosis or necrosis, both types of death being followed by danger-associated molecular patterns (DAMPs) release. DAMPs can act on Kupffer cells (KCs) by activating them and trigger inflammatory cytokines and chemokines release that can act on hepatocytes, HSCs and on themselves. DAMPs can also be involved in promoting HSCs activation characterized by an increase in extracellular matrix (ECM) accumulation, collagen type I, fibronectin, metalloproteinase (MMP-9, 13), tissue inhibitor of metalloproteinases (TIMP-1), all fibrogenic markers. Pyroptosis is induced by DAMPs and triggers a self-perpetuating loop as more DAMPs are released following pyroptotic death. Figure created with Biorender.com.

\section{Events Triggering Hepatocyte Death, Release of DAMPs and Inflammatory Signals}

Hepatocytes are parenchymal cells of the liver and are targeted by many hepatotoxic agents that may induce their death [6,7]. These hepatotoxic agents could be viruses, bacteria, bile acids, alcohol metabolites, etc. [11,12] that act as extracellular or intracellular cell death signals $[4,13]$. Most known extrinsic signals are members of the tumor necrosis factor (TNF) protein superfamily such as TNF- $\alpha$, FASL, TNF-related apoptosis-inducing ligand (TRAIL) [14,15]. Of note is that TNF- $\alpha$ is massively produced when hematopoietic cells are exposed to bacteria or lipopolysaccharide (LPS) [16]. TNF- $\alpha$ is intercepted by death receptors such as ligand-bound TNR receptor 1 (TNFR1) $[13,17]$ and this interaction is followed by reactive oxygen species (ROS) production and NF- $\mathrm{kB}$ activation $[18,19]$. Cell death can also follow intrinsic pathways triggered by accumulation of saturated fatty acids or response to redox stress $[4,20,21]$. Especially in NASH, lipotoxicity induces the endoplasmic reticulum (ER) stress response and the unfolded protein response (UPR). In mild ER stress conditions, homeostasis can be re-established [22], however, prolonged ER stress causes cell death by apoptosis via Bcl-2 family proteins $[23,24]$.

Apoptosis is not the only type of cell death hepatocytes can follow, there are multiple other types of cell death (necrosis, necroptosis, pyroptosis) that can occur in the liver with different consequences on liver inflammation and fibrogenesis [25]. Necrosis is a type of cell death that occurs in hepatocytes, but unlike apoptosis, it generates more inflammatory signals. It is caused by mitochondrial deterioration, loss of membrane potential and ATP depletion that results in a process called oncosis characterized by cell swelling, coagulation of the cytoplasm and plasma membrane rupture followed by the release in the extracellular environment of the cellular content $[25,26]$. Necrosis is known as an unprogrammed cell death, but there are some forms of necrosis which are regulated, such as necroptosis. This type 
of cell death is regulated via death receptors (DRs) signaling such as pattern-recognition receptors (PRRs) or intracellular sensors $[27,28]$. Necroptosis follows the same upstream signaling pathway as apoptosis, but upon caspase-8 loss, it initiates necrosome assembly that results in cell death by cellular swelling and plasma membrane rupture with subsequent release of the cellular content $[29,30]$.

Hepatocytes death further impacts HSCs activation in other ways as well. Their apoptotic bodies are engulfed by HSCs and it triggers the upregulation of transforming growth factor- $\beta 1$ (TGF- $\beta 1$ ) and procollagen 1 (I) and activation of reduced nicotinamide adenine dinucleotide phosphate (NADPH) oxidase which leads to superoxide production [31]. Moreover, dying hepatocytes release damage-associated molecular patterns (DAMPs) that act not only on HSCs directly by stimulating their activation, but also indirectly by inducing sterile inflammation on other cell types responsible for further hepatocyte damage [32].

DAMPs or alarmins are endogenous factors which are involved in various cellular functions in the healthy cells, but during cell death they are released in the extracellular medium and can induce sterile inflammation [26]. To date, there are multiple DAMPs identified that are usually intercepted by PRRs such as toll-like receptors (TLRs), cytosolic nucleotide-binding domain and leucine-rich repeat containing receptors (NOD-like receptors, NLRs) or C-type receptors (CLRs) [33]. This in turn stimulates the production of cytokines and activates the inflammatory response [34], along with the assembly of the inflammasome.

A partial list of DAMPs is presented in Table 1 with several factors very diverse, but all involved in sterile inflammation stimulation. One of the important sources of DAMPs is the mitochondria that can release mitochondrial DNA [33-36], formyl peptides [26,37], ATP and UTP [38-40]. MtDNA from damaged hepatocytes triggers TLR9, inflammasome and cyclic GMP-AMP synthase-stimulator of interferon genes (cGAS-STING) [41]. ATP is secreted through pannexin 1 channels from dying hepatocytes [42]. The ATP is intercepted by members of the P2 receptors family (P2RX7, P2Y2) and causes inflammasome activation, production of IL- $1 \beta$ and neutrophils infiltration $[40,43]$. In high concentrations, extracellular ATP initiates pore formation that can lead to cell death $[44,45]$.

Table 1. List of DAMPs, receptors and their function in liver inflammation.

\begin{tabular}{ccc}
\hline DAMPs & Receptor & Function \\
\hline ATP, UTP & P2RX7, P2Y2, NLRP3 & $\begin{array}{c}\text { Purine metabolites } \\
\text { NLRP3 inflammasome activation } \\
\text { Neutrophils infiltration }\end{array}$ \\
\hline Defensins & TLR4, CCR6 & \\
\hline Fatty acids & TLR4 & Inflammatory signaling \\
\hline HSPs (HSPA1A, HSPB1) & TLR2, TLR4, CD14, CD91 & $\begin{array}{c}\text { Intracellular chaperons } \\
\text { Adjuvants }\end{array}$ \\
\hline CRT, ERp57 & CD91 & ER chaperons \\
\hline HMGB1 & TLR4, RAGE, & Multifunctional nuclear factor \\
Profibrogenic effects
\end{tabular}


High mobility group box 1 (HMGB1) is a non-histone chromatin-binding protein released during cell death or by different immune cells as a response to other DAMPs [46-49]. It can be intercepted by some receptors from the TLRs family (TLR2, 4 and 9) and RAGE. Both receptor types respond to HMGB1 by activating intracellular signals such as nuclear factor (NF)- $\mathrm{kB}$ and the mitogen-activated protein kinase (MAPK) pathway [50]. HMGB1 can act in complex with other proinflammatory factors (single-stranded DNA, LPS, IL-1 $\beta$ and nucleosomes) to initiate inflammation [51]. On HSCs, recombinant HMGB1 promotes $\alpha$-smooth muscle actin ( $\alpha$-SMA) expression and inhibits metalloproteinase-2 (MMP-2) activity [52]. Suppression of HMGB1 expression is correlated with downregulation of $\alpha$-SMA and collagen (types I and III) in HSCs [53]. When acting along with TGF- $\beta$, HMGB1 stimulates the expression of more profibrogenic factors (collagen $\alpha 2$ and $\alpha$-SMA) [54].

Uric acid is able to act as DAMP when found in a crystallization form after exposure to the extracellular environment [33-55]. This form of uric acid stimulates inflammation without binding to an extracellular receptor and can cause phagosome rupture and activation of cytosolic proteases [35]. In the case of cellular injury, histones are also released in the extracellular medium and act as DAMPs. They bind with TLR2/4 and induce sterile inflammation with NLRP3 inflammasome formation [36,56-58]. Nuclear DNA released from acetaminophen-exposed hepatocytes interacts with TLR9 and additionally to its NLRP3 inflammasome activation [59], nDNA also stimulates HSCs transdifferentiation to myofibroblasts [60]. Free fatty acids (FFA) are other proposed DAMPs which can activate TLR4 by fentuin-A modulation. Studies on mice show a link between fentuin-A expression and TLR4-mediated inflammatory signaling in adipose tissue. However, there is evidence fentuin-A might act in the liver as well since its levels are elevated in non-alcoholic fatty liver disease (NAFLD) [22]. Other DAMPs worth mentioning are CRT and ERp57 that bind to the CD91 receptor and represent ER chaperons. They are released in ER stress via the Golgi secretory pathway [61,62].

Recent studies have identified new DAMPs associated with liver injury. Peroxiredoxin-1 (Prdx1) is one of them and it is recognized by TLR2/4 and further initiates NLRP3 inflammasome [63-65]. $\operatorname{Prdx} 1$ is involved in the production of pro-inflammatory cytokines such as IL-1 $\beta$, IL- 6 and TNF- $\alpha$ by acting on NF-KB and NLRP3 inflammasome pathways. In a study by He et al., [64] levels of circulating Prdx1 in mice with acute liver injury (ALI) are increased, as well as for patients with ALI.

Some DAMPs may present an anti-inflammatory effect when they interact with other receptors. Such is the case for HMGB1 and HSPs when binding to CD24 or sialic acid-binding Ig-like lectin 10 (SIGLEC10) [66]. Additionally, IL-33 which is a transcription factor in healthy cells, during inflammation, is thought to inhibit inflammatory reactions $[67,68]$. Heat-shock proteins (HSPA1A, HSPB1) represent other potential DAMPs that interact with TLR2/4 and are involved in the hepatic response to ischemia reperfusion (IR). Their role might also be anti-inflammatory and act as intracellular chaperons $[69,70]$.

\section{Activation of KCs and Inflammatory Signaling}

\subsection{Inflammatory Signals from Kupffer Cells and Other Inflammation-Related Cells}

Kupffer cells (KCs) are specialized mesenchymal macrophages that are part of the reticuloendothelial system (RES) and make up around $30 \%$ of hepatic sinusoidal cells. These types of cells have an important role in the defense against infections derived from the gastrointestinal tract. KCs can be activated by a number of phagocytosable particles and soluble substances by binding to specific PRRs such as TLRs, mannose receptors and NOD-like receptors (NLRs) [71]. For instance, KCs can respond to exposure to LPS by binding to TLR4 which leads to production of inflammatory cytokines (TNF- $\alpha$, IL-1 $\beta$, IL-6, IL-12, IL-18, etc.) and other chemokines [72], most of them being actively involved in HSCs activation (Table 2) [5,73-75]. Other macrophages recruited to the liver in the case of inflammation, are also involved in secretion of pro- and anti-inflammatory cytokines, depending on their type (proinflammatory M1 or immunosuppressive M2, respectively). M1 macrophages release TNF- $\alpha$, IL-1 and IL- 6 when stimulated by interferon- $\gamma$ (IFN- $\gamma$ ), LPS, TNF- $\alpha$, or IL-17, while M2 
macrophages produce IL-10, TGF- $\beta$, platelet-derived growth factor (PDGF) and epidermal growth factor (EGF) when stimulated by IL-4, IL-10, or IL-13 (Table 2) [76-78].

Table 2. Inflammatory cytokines involved in liver inflammation.

\begin{tabular}{|c|c|c|c|}
\hline $\begin{array}{l}\text { Inflammatory } \\
\text { Signal }\end{array}$ & Producing Cells & Target Cells & Role \\
\hline TNF- $\alpha$ & $\begin{array}{l}\text { KCs, M1 macrophages, } \\
\text { MAIT cells }\end{array}$ & Activated HSCs & Pro-survival of aHSCs \\
\hline TGF- $\beta 1$ & $\begin{array}{l}\text { aHSCs, KCs, hepatocytes, } \\
\text { LSECs }\end{array}$ & HSCs, KCs & $\begin{array}{l}\text { HSCs activation, upregulation of } \\
\text { matrix-producing genes }\end{array}$ \\
\hline IL-17 & Th cells, MAIT cells & KCs, M1 macrophages & $\begin{array}{l}\text { Indirectly HSCs activation, HSCs } \\
\text { collagen type I deposition }\end{array}$ \\
\hline IL-10 & M2 macrophages & M2 macrophages, aHSCs & $\begin{array}{c}\text { Downregulating pro-inflammatory } \\
\text { processes, senescence of aHSCs }\end{array}$ \\
\hline IL-6 & $\begin{array}{l}\text { KCs, M1 macrophages, } \\
\text { myofibroblasts }\end{array}$ & Hepatocytes & $\begin{array}{l}\text { Inhibition of apoptosis and } \\
\text { regeneration stimulation of } \\
\text { hepatocytes }\end{array}$ \\
\hline IL-1 $\beta$ & $\mathrm{KCs}$ & HSCs, hepatocytes & $\begin{array}{c}\text { Pro-inflammatory effect, acts } \\
\text { together with Il-1 } \alpha, \text { HSCs } \\
\text { proliferation }\end{array}$ \\
\hline $\mathrm{IL}-1 \alpha$ & $\mathrm{KCs}$ & HSCs, hepatocytes & $\begin{array}{l}\text { Pro-inflammatory effect, acts } \\
\text { together with Il- } 1 \alpha\end{array}$ \\
\hline IL-22 & $\begin{array}{l}\text { KCs, innate immunity } \\
\text { cells }\end{array}$ & Hepatocytes & Pro-survival signals on hepatocytes \\
\hline
\end{tabular}

Another great source of inflammation in the liver is brought on by cells involved in innate immunity, such as Th17 cells, natural killer (NK) cells and mucosal-associated invariant T (MAIT) cells. Th17 cells are responsible for IL-17 production, a cytokine that stimulates liver fibrosis. NK cells are activated by the release of retinoic acid from transdifferentiating HSCs and they further attack activated HSCs and produce IFN- $\gamma[5,14,79,80]$. MAIT cells are innate-like T cell populations [81] that are found in the peri-biliary areas of portal tracts and secrete cytokines such as IL-17, granzyme B (Gr-B), IFN- $\gamma$ and TNF- $\alpha$. Activated MAIT cells induce a proinflammatory behavior of hepatic myofibroblasts by stimulation of IL-8 and IL-6 production [82].

TGF- $\beta 1$ is a multifunctional cytokine and one of the key regulators and promoters of liver fibrosis stimulating HSCs transdifferentiation from quiescent cells to activated myofibroblasts [83]. TGF- $\beta 1$ is synthetized by activated HSCs (aHSCs), KCs, hepatocytes and liver sinusoidal endothelial cells (LSECs) and exerts its role on liver cells via type I and II TGF- $\beta$ receptors (T $\beta$ RI and T $\beta$ RII), as well as SMAD-mediated intracellular signals $[7,84]$. TGF- $\beta 1$ mediates transdifferentiation of HSCs to myofibroblasts by upregulation of Notch pathway markers and $\alpha$-SMA [83]. Additionally, it stimulates expression of collagen type I and other matrix-producing genes [85].

TNF- $\alpha$ is a pleiotropic cytokine produced mainly by KCs and other inflammatory-related cells that stimulates cell proliferation, inflammatory response and even cell death [86]. In aHSCs, TNF- $\alpha$ can induce a pro-survival signal by activating NF- $\mathrm{KB}, \mathrm{Bcl}-\mathrm{XL}$ and p21 [87]. Additionally, it stimulates IL-6 and IL-8 production [4,18]. As of cell death stimulation, TNF- $\alpha$ acts on receptor TNF-R1 that leads to interaction with TNF receptor-associated protein with death domain (TRADD) and forms a complex with TNF- $\alpha$ receptor-associated factor 2 (TRAF2), receptor-interacting kinase (RIP) and adapter molecule Fas-associated death domain (FADD) that further activate caspase- 8 and induce apoptosis [88]. 


\subsection{Proinflammatory Cytokines}

Among all cytokines present in liver fibrosis, IL-17 and IL-1 families distinguish themselves as important proinflammatory cytokines. IL-17 acts by two different mechanisms to exert its profibrogenic effect. Firstly, IL-17 can induce production of IL-6, IL-1 $\beta$, TNF- $\alpha$ and TGF- $\beta 1$ in KCs and other macrophages that will further stimulate, indirectly, HSCs activation. Secondly, IL-17 can also act directly on HSCs, by promoting collagen type I deposition and an increase in fibrogenic markers expression such as $\alpha$-SMA and TGF- $\beta 1[78,89]$.

IL-1 cytokine has a pro-fibrogenic effect on HSC sy upregulation of MMP-9, MMP-13 and tissue inhibitor of metalloproteinases (TIMP-1) [90]. IL-1 family comprises of 11 members and some of the best known and most studied are IL- $1 \alpha$, IL-1 $\beta$ and IL-18 [91]. IL- $1 \alpha$ and IL-1 $\beta$ act synergistically in promoting development of liver fibrosis, as shown in a study that blocking the expression of either of them in vivo was sufficient to protect mice from developing steatohepatitis [92]. IL-1 $\beta$ is mostly produced by KCs and has pro-inflammatory effects in the development of NASH by inhibiting peroxisome proliferator-activated receptor- $\alpha$ (PPAR- $\alpha$ ) and enhancing the TNF- $\alpha$ role in cell death stimulation $[93,94]$. Depending on the type of liver fibrosis driving infection, IL-1 $\beta$ can be one of the main factors underlying inflammation as in the case of chronic HBV infection, but not in chronic HCV infection [95]. In rat HSCs, IL-1 $\beta$ stimulates proliferation via IL-1 type I receptor (IL-1R1), JNK and AP-1 pathway [96].

\subsection{Anti-Inflammatory Cytokines}

IL-10 is involved in downregulating the pro-inflammatory processes in liver fibrosis [7]. In vivo studies showed that IL-10 inhibits the expression of aHSCs markers demonstrating its anti-fibrotic effects $[97,98]$. In a more recent study, IL-10 was shown to promote cellular death of aHSCs by senescence and upregulation of p53 and p21 expression [98]. Another anti-inflammatory cytokine is IL-22 that belongs to the IL-10 family and it is produced by innate immune system cells [99-101]. IL-22 acts upon hepatocytes via a transmembrane receptor complex with two subunits (IL-22 receptor 1 and IL-10 receptor 2) [102]. It induces upregulation of anti-apoptotic and mitogenic proteins, promoting hepatocyte survival in the context of liver injury [103-105]. IL-22 can also activate signal transducer and activator of transcription 3 (STAT3) signaling in HSCs and induce their death by senescence, contributing to resolution of liver fibrosis [105]. At the same time, IL-22 was shown to inactivate HSCs by downregulation of the TGF- $\beta 1 /$ Notch signaling pathway in HSCs [106].

IL-6 is a pleiotropic cytokine, mostly produced by KCs that can act in acute and chronic inflammation with a different type of action, pro- or anti-inflammatory. It can regulate NF- $\mathrm{KB}$ and Ras-MAPK pathways to inhibit apoptosis and stimulate regeneration in hepatocytes $[107,108]$. IL-6 is a major activator of STAT3 involved in the development of many liver diseases and especially hepatocellular carcinoma [109]. Additionally, IL-6/STAT3 signaling has been correlated with liver fibrosis and HSC activation [110,111].

\section{Sterile Inflammation and Inflammasome Complex}

The inflammasome is a cytosolic multiprotein complex comprised of NLR, apoptosis-associated speck-like protein containing a CARD (ASC) and caspase 1/5 [112,113]. They are responsible for the cleavage and secretion of pro-IL1 $\beta$ and pro-IL18 [114] (Figure 2). There are two types of NLRs depending on the $\mathrm{N}$-terminal domain, NOD-like receptor family with pyrin domain (NLRP) and NOD-like receptor family with caspase activation and recruitment domain (CARD) (NLRC) [115]. Depending on the type of receptor, there are several types of inflammasomes such as NLRP1, 2, 3, 6, 10, 12, NLRC4 and AIM2 that may act on different pathways, but they all activate caspase-1. So far, the activity of only NLRP1, 3, NLRC4 and AIM2 inflammasomes was identified in liver inflammation, a great number of studies being focused on the role of NLRP3 inflammasome [116]. Each type of inflammasome is activated by different signals and has different roles depending on the cell type 
involved [113]. NLRP1 inflammasome was shown to be activated by anthrax lethal toxin, bacterial muramyl dipeptide and infection with Toxoplasma gondii [117]. Additionally, NLRP1 can be activated by metabolic disturbances such as ATP-depletion $[118,119]$. NLRC4 inflammasome is thought to be mostly activated as a defensive mechanism against bacterial infection (Salmonella, Legionella and Shigella) [113]. However, other non-bacterial factors can induce NLRC4 activation as well, such as free fatty acids (FFA) shown in a recent study by Chen et al. [120]. The study was conducted on a NAFDL in vitro cell model based on HepG2 cells and THP-1 macrophages co-culture. The study showed that activation of NLRC4 inflammasome is TNF- $\alpha$ mediated and initiates pyroptosis with NLRC4 translocation in the mitochondria. AIM2 inflammasome responds to cytosolic double-stranded DNA (dsDNA) through its C-terminal DNA binding domain and $N$-terminal pyrin domain [121]. This type of inflammasome can be activated by dsDNA originated from both the host or other pathogens such as Listeria monocytogenes, Schistosoma mansoni [122], or viruses such as chronic hepatitis B virus [123]. Activation of AIM2 inflammasome triggers cell death by apoptosis. In the case of some bacterial infections, a possible crosstalk is possible between AIM2 and NLRP3 inflammasomes as it was recently hypothesized in a study by Chen et al. (2019) [120]. NLRP3 does not trigger apoptosis like the other NLRs, but it is mostly involved in regulating innate immune response as a sensor for tissue stress [124].

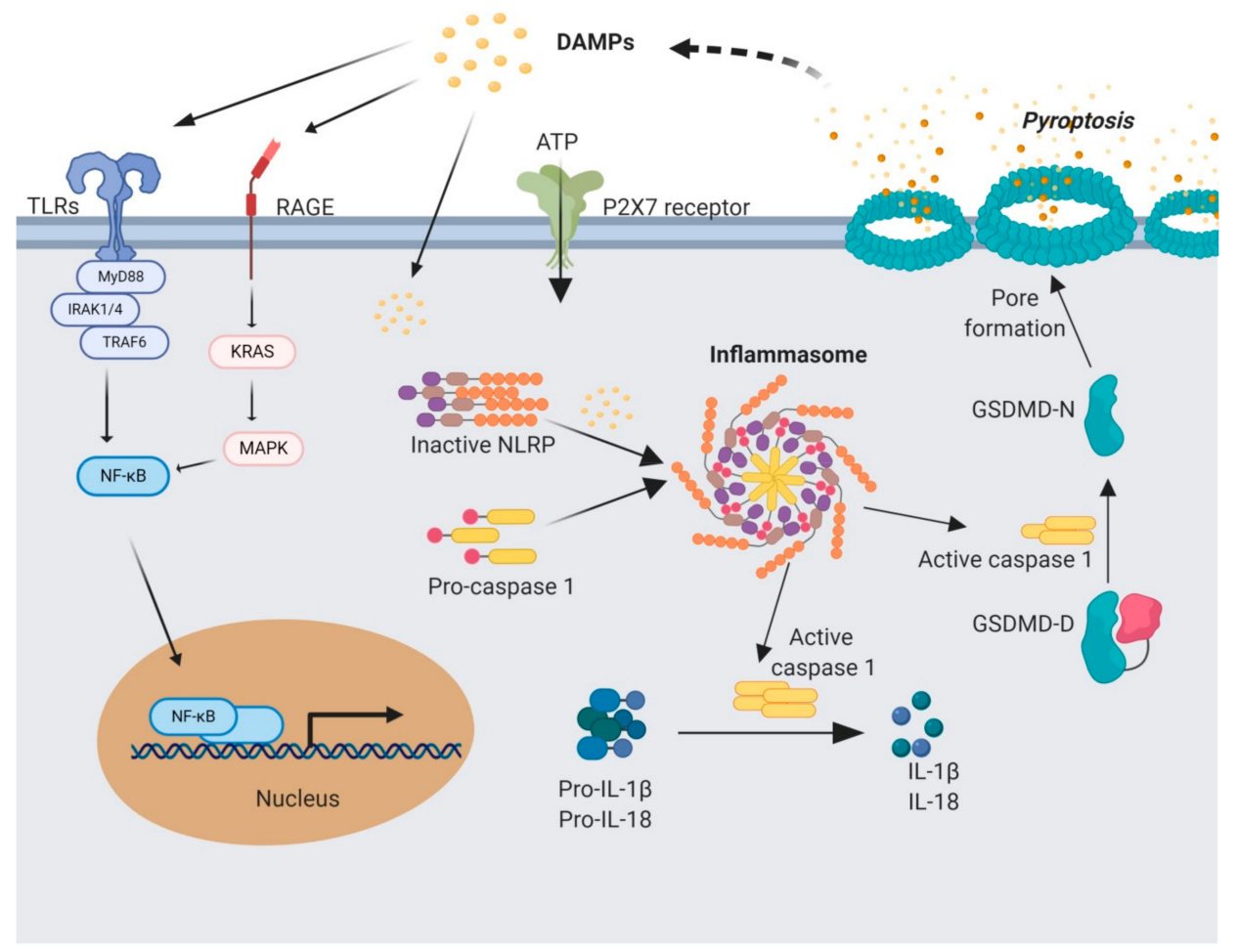

Figure 2. Mediators involved in sterile inflammation signaling and pyroptosis. Sterile inflammation is triggered by a first signal triggered by DAMPs that can act on receptors such as toll-like receptors (TLRs), RAGE and PRX7. Activating signaling by TLRs initiates a cascade that translocates NF- $\mathrm{B}$ in the nucleus and stimulates pro-IL-1 $\beta$ and pro-IL-18 expression. A second signal stimulates inflammasome assembly from NOD-like Receptors (NLRs), caspase activation and recruitment domain (CARD) and pro-caspase 1 that is cleaved and activated within this complex. Activated caspase- 1 further activates IL-1 $\beta$ and IL-18 and also releases the $N$-terminal of gasdermin, responsible for pore formation and initiation of pyroptosis. IL-1 $\beta$, IL-18, along with DAMPs are released from the cell by means of the pores and initiates a self-perpetuating loop of sterile inflammation. Figure created with BioRender.com.

Regardless of its type, the inflammasome is a key modulator of the events triggering liver fibrosis, controlling the activation of proinflammatory caspase 1 . In response to this activation and release of IL-1 $\beta$ and IL-18 cytokines, an abnormal wound healing and pro-regenerative signal is initiated, further 
leading to HSCs activation [6]. Recent studies have shown that NLRP3 activation is actually required for hepatic inflammation and fibrosis [125], although it is not clear yet if this inflammasome assembly directly leads to HSC activation or if it first creates the necessary inflammatory microenvironment that triggers itself HSC recruitment from the quiescent state and change in phenotype. What is more, NLRP3 overactivation in vivo long term resulted in increase of fibrogenesis-related markers and collagen secretion, without significant elevation of the inflammatory profile.

Although the general overview suggests that the inflammasome activation has a negative impact on cell fate by directly inducing pyroptosis, there is recent evidence on the dual role of inflammasomes in liver diseases [126]. On one hand, inflammasomes are needed for protection against danger signals, oxidative stress and pathogen infections, but on the other hand their overactivation favors the development of several liver pathologies. In addition, NLRP3 activation may lead also to abnormal wound healing events associated to fibrosis, in parallel to triggering pyroptosis. Nevertheless, NLRP3 inflammasome acts indirectly on the adaptative immune system by stimulating caspase- 1 and IL-1 $\beta$ production, which favor Th17 cell differentiation and secretion of IL-17, resulting in continuous liver fibrosis state [127]. All these facts argue that the dual role of inflammasomes in liver fibrosis and might represent an opportunity to develop therapies targeting them. Up to now, these therapies were designed to act at either the level of caspase-1 (caspase inhibitors) or at the level of IL-1 $\beta$ signaling (IL-1 $\beta$ inhibitors) [128].

Liver fibrosis state was found to be regulated both directly and indirectly by inflammasomes [128]. The indirect pathway involves HSCs activation by IL-1 $\beta$ and IL-18 derived from KCs [129], while the direct inflammasome activation in HSCs was found when inducing TGF- $\beta$ upregulation by treatment with uric acid crystals or derivatives [130,131].

The release of fully functional IL-1 $\beta$ and IL-18 cytokines depends on a two-step process. TLRs send the first signal that initiates the transcription of cytokines pro-IL-1 $\beta$ and pro-IL-18 which require post-transcriptional processing by caspase- 1 cleavage to activate them. However, caspase- 1 , expressed as pro-caspase- 1 also needs to be activated by assembly in the inflammasome complex. The second signal initiates the inflammasome formation and activated caspase- 1 cleave and release IL-1 $\beta$ and IL-18 cytokines [132,133]. The second signal needed for inflammasome activation can be transmitted in multiple ways. Cytosolic $\mathrm{Ca}^{2+}$ from the release of mitochondrial reactive oxygen species (mROS) and mitochondrial DNA (mtDNA) can activate NLRP3 inflammasome [134]. G protein-coupled $\mathrm{Ca}^{2+}$-sensing receptors (CASR and GPRC6A) and $\mathrm{Ca}^{2+}$-permeable channels (transient potential melastatin-like 2 (TRPM2), TRPV2 and TRPM7) ensure NLRP3 activation [135-137]. Another stimulant can be endoplasmic reticulum (ER) stress modulated by thioredoxin-interacting protein (TXNIP) [138-140].

Caspase- 1 activation also leads to the release from the cell of IL- $1 \alpha$ and members of the caspase- 1 secretome such as HMGB1 [141-143]. Their release in the extracellular medium stimulates the immune system as they are perceived as DAMPs, proving this as a self-perpetuating loop of inflammation [6,144].

Furthermore, activated caspase- 1 can initiate canonical pyroptosis, a lytic form of programmed cell death characterized by cell swelling, cell lysis and the release of the cytoplasmic content $[145,146]$. It has evolved as a way of removing intracellular pathogens in a distinctive way compared to other forms of cell death [25]. There are additional caspases involved in the onset of noncanonical pyroptosis along with caspase- 1 activated by the inflammasome, such as caspase-4, 5, 8, 11 and 12 [147-149]. The specific role of activated caspases is to cleave gasdermin-D (GSDMD) and the resulting $N$-terminal peptide fragment binds to the plasma membrane. This binding initiates pore formation that leads to membrane integrity loss and cellular content release followed by cellular death $[148,150,151]$. This type of cell death enhances the immune response by releasing triggers such as ATP, HMGB- 1 and IL- $1 \alpha$, but also IL-1 $\beta$ and IL-18 inflammatory cytokines $[148,152]$. Pyroptosis is an important process involved in the development of different types of liver diseases, with various levels of expression in all the liver cell types. It occurs most commonly in macrophages and hepatocytes and can be triggered by DAMPs released by primary damaged hapatocytes [149]. In a study of Mirshafiee et al. [153] it was shown that 
KCs undergo pyroptosis as a result of direct exposure to rare earth oxides. Moreover, in another recent study, NLPR3 inflammasome in KCs was demonstrated to play an important role in the progress of NASH in an animal model [154]. Hepatocytes can also be stimulated to activate inflammasomes and follow pyroptotic death. In a study by Lebeaupin et al. [155], it was shown that ER stress in a mice model of steatohepatitis leads to NLRP3 inflammasome overexpression resulting in liver inflammation and hepatocytes undergoing pyroptosis. Another study by Heo et al. confirmed NLRP3 inflammasome overexpression and subsequent pyropotosis in hepatocytes after ethanol exposure in human and animal liver samples with alcoholic hepatitis [156].

As pyroptosis was demonstrated to be induced under certain conditions in KCs, hepatocytes and HSCs, further studies confirmed the relevance of this cell death in the development of different types of liver diseases [95,157-159]. Some of the most studied liver diseases are NAFLDs that could vary from steatosis to fibrosis after prolonged chronic inflammation in the liver. In NASH, NLRP3 inflammasome is activated, GSDM is cleaved and IL-1 $\beta$ and IL-18 are released after pyroptosis, molecules that contribute to the progress of the disease $[149,160,161]$. In alcoholic liver disease (ALD) development, the role of pyroptosis has been as well established in several studies [156,162]. Particularly, one study showed that NLRP3 deficiency in alcohol-fed mice protected the liver against inflammation and ameliorated liver damage and steatosis progress [157].

\section{Conclusions}

Liver fibrosis represents a reversible pathological condition, closely related to inflammation, which affects the hepatic structure and function by accumulation of excessive ECM. Under chronic stimuli, liver fibrosis can progress to irreversible stages of liver damage such as cirrhosis or hepatocellular carcinoma. The reversibility of liver fibrosis is influenced by the pro-fibrogenic signals and the microenvironment created by the interplay and coordination between hepatocytes, Kypffer cells and HSCs. Under the action of hepatotoxic agents, hepatocytes are the first cells to be affected by undergoing cell death, releasing danger signals. KCs and other inflammatory-related cells are also alerted by the presence of hepatotoxic agents in the liver and once activated, produce inflammatory cytokines that further act on all the other cell types to maintain the inflammatory state. Therefore, this cellular interplay highly affects the overall response to danger signals, in most cases, leading to HSCs activation and supporting their transdifferentiation towards a myofibroblastic phenotype, highly proliferative and responsible for matrix accumulation.

Sterile inflammation further promotes fibrogenesis and the inflammasome assembly is responsible for a self-perpetuating loop of an inflammatory state. Contradictory to the general belief that the inflammasome activation has a negative outcome favoring cell death by pyroptosis, actually inflammasomes display a dual role in liver diseases. On one hand, inflammasomes are needed for protection against danger signals, oxidative stress and pathogen infections, but on the other hand their overactivation may lead to abnormal wound healing events associated with fibrosis, in parallel to triggering pyroptosis.

There are still many unknown mechanisms of inflammasome signaling in liver fibrosis that will require further studies to shed light over the correlation between inflammasome types and their role in different types of liver injury. All this knowledge on the subject can open opportunities to develop therapies that target inflammasomes, to either inhibit inflammasome assembly, or act on the downstream signaling molecules.

Author Contributions: Conceptualization, S.R.I., S.D., A.H. and M.C.; resources, A.H. and M.C.; writing-original draft preparation, S.R.I.; writing-review and editing, S.R.I. and S.D.; visualization, S.R.I. and S.D.; supervision, M.C. and A.H.; project administration, S.D. and M.C.; funding acquisition, M.C. All authors have read and agreed to the published version of the manuscript.

Funding: This work was supported by several grants of the Romanian Ministry of Research and Innovation, CCDI-UEFISCDI, project numbers PN-III-P1-1.2-PCCDI-2017-0407/INTELMAT, PN-III-P1-1.2-PCCDI-2017-0341/ PATHDERM, PN-III-P1-1.2-PCCDI-2017-0782/REGMED, within PNCDI III. 
Conflicts of Interest: The authors declare no conflict of interest. The funders had no role in the design of the study; in the collection, analyses, or interpretation of data; in the writing of the manuscript, or in the decision to publish the results.

\section{References}

1. Puche, J.E.; Saiman, Y.; Friedman, S.L. Hepatic stellate cells and liver fibrosis. Compr. Physiol. 2013, 3, 1473-1492.

2. Weiskirchen, R.; Weiskirchen, S.; Tacke, F. Organ and tissue fibrosis: Molecular signals, cellular mechanisms and translational implications. Mol. Asp. Med. 2019, 65, 2-15. [CrossRef] [PubMed]

3. Schattenberg, J.M.; Galle, P.R.; Schuchmann, M. Apoptosis in liver disease. Liver Int. 2006, 26, 904-911. [CrossRef] [PubMed]

4. Brenner, C.; Galluzzi, L.; Kepp, O.; Kroemer, G. Decoding cell death signals in liver inflammation. J. Hepatol. 2013, 59, 583-594. [CrossRef]

5. Zhangdi, H.-J.; Su, S.-B.; Wang, F.; Liang, Z.-Y.; Yan, Y.-D.; Qin, S.-Y.; Jiang, H.-X. Crosstalk network among multiple inflammatory mediators in liver fibrosis. World J. Gastroenterol. 2019, 25, 4835-4849. [CrossRef] [PubMed]

6. Alegre, F.; Pelegrin, P.; Feldstein, A.E. Inflammasomes in Liver Fibrosis. Semin. Liver Dis. 2017, 37, $119-127$. [CrossRef] [PubMed]

7. Zhou, W.-C.; Zhang, Q.-B.; Qiao, L. Pathogenesis of liver cirrhosis. World J. Gastroenterol. 2014, 20, 7312-7324. [CrossRef] [PubMed]

8. Safadi, R.; Friedman, S.L. Hepatic fibrosis-role of hepatic stellate cell activation. MedGenMed 2002, 4, 27. [PubMed]

9. Gressner, A.M.; Weiskirchen, R. Modern pathogenetic concepts of liver fibrosis suggest stellate cells and TGF-beta as major players and therapeutic targets. J. Cell. Mol. Med. 2006, 10, 76-99. [CrossRef]

10. He, Y.; Huang, C.; Zhang, S.; Sun, X.; Long, X.; Li, J. The potential of microRNAs in liver fibrosis. Cell Signal. 2012, 24, 2268-2272. [CrossRef]

11. Bataller, R.; Brenner, D.A. Liver fibrosis. J. Clin. Investig. 2005, 115, 209-218. [CrossRef] [PubMed]

12. Schuppan, D. Liver fibrosis: Common mechanisms and antifibrotic therapies. Clin. Res. Hepatol. Gastroenterol. 2015, 39 (Suppl. 1), S51-S59. [CrossRef]

13. Luedde, T.; Kaplowitz, N.; Schwabe, R.F. Cell death and cell death responses in liver disease: Mechanisms and clinical relevance. Gastroenterology 2014, 147, 765-783.e4. [CrossRef] [PubMed]

14. Jiang, J.X.; Török, N.J. Liver Injury and the Activation of the Hepatic Myofibroblasts. Curr. Pathobiol. Rep. 2013, 1, 215-223. [CrossRef] [PubMed]

15. Muppidi, J.R.; Tschopp, J.; Siegel, R.M. Life and death decisions: Secondary complexes and lipid rafts in TNF receptor family signal transduction. Immunity 2004, 21, 461-465. [CrossRef] [PubMed]

16. Pfeffer, K.; Matsuyama, T.; Kündig, T.M.; Wakeham, A.; Kishihara, K.; Shahinian, A.; Wiegmann, K.; Ohashi, P.S.; Krönke, M.; Mak, T.W. Mice deficient for the $55 \mathrm{kd}$ tumor necrosis factor receptor are resistant to endotoxic shock, yet succumb to L. monocytogenes infection. Cell 1993, 73, 457-467. [CrossRef]

17. Akazawa, Y.; Gores, G. Death Receptor-Mediated Liver Injury. Semin. Liver Dis. 2007, 27, 327-338. [CrossRef]

18. DiDonato, J.A.; Mercurio, F.; Karin, M. NF-кB and the link between inflammation and cancer. Immunol. Rev. 2012, 246, 379-400. [CrossRef]

19. Han, D.; Ybanez, M.D.; Ahmadi, S.; Yeh, K.; Kaplowitz, N. Redox regulation of tumor necrosis factor signaling. Antioxid. Redox Signal. 2009, 11, 2245-2263. [CrossRef]

20. Ibrahim, S.H.; Kohli, R.; Gores, G.J. Mechanisms of lipotoxicity in NAFLD and clinical implications. J. Pediatr. Gastroenterol. Nutr. 2011, 53, 131-140. [CrossRef]

21. Malhi, H.; Gores, G.J. Molecular mechanisms of lipotoxicity in nonalcoholic fatty liver disease. Semin. Liver Dis. 2008, 28, 360-369. [CrossRef] [PubMed]

22. Ogata, M.; Hino, S.; Saito, A.; Morikawa, K.; Kondo, S.; Kanemoto, S.; Murakami, T.; Taniguchi, M.; Tanii, I.; Yoshinaga, K.; et al. Autophagy is activated for cell survival after endoplasmic reticulum stress. Mol. Cell. Biol. 2006, 26, 9220-9231. [CrossRef] [PubMed]

23. Martinou, J.-C.; Youle, R.J. Mitochondria in apoptosis: Bcl-2 family members and mitochondrial dynamics. Dev. Cell 2011, 21, 92-101. [CrossRef] [PubMed] 
24. Weber, A.; Boger, R.; Vick, B.; Urbanik, T.; Haybaeck, J.; Zoller, S.; Teufel, A.; Krammer, P.H.; Opferman, J.T.; Galle, P.R.; et al. Hepatocyte-specific deletion of the antiapoptotic protein myeloid cell leukemia-1 triggers proliferation and hepatocarcinogenesis in mice. Hepatology 2010, 51, 1226-1236. [CrossRef] [PubMed]

25. Iorga, A.; Dara, L. Cell death in drug-induced liver injury. Adv. Pharmacol. 2019, 85, 31-74. [PubMed]

26. Galluzzi, L.; Bravo-San Pedro, J.M.; Vitale, I.; Aaronson, S.A.; Abrams, J.M.; Adam, D.; Alnemri, E.S.; Altucci, L.; Andrews, D.; Annicchiarico-Petruzzelli, M.; et al. Essential versus accessory aspects of cell death: Recommendations of the NCCD 2015. Cell Death Differ. 2015, 22, 58-73. [CrossRef]

27. Degterev, A.; Hitomi, J.; Germscheid, M.; Ch'en, I.L.; Korkina, O.; Teng, X.; Abbott, D.; Cuny, G.D.; Yuan, C.; Wagner, G.; et al. Identification of RIP1 kinase as a specific cellular target of necrostatins. Nat. Chem. Biol. 2008, 4, 313-321. [CrossRef]

28. Newton, K.; Manning, G. Necroptosis and Inflammation. Annu. Rev. Biochem. 2016, 85, 743-763. [CrossRef]

29. Linkermann, A.; Green, D.R. Necroptosis. N. Engl. J. Med. 2014, 370, 455-465. [CrossRef]

30. Sun, L.; Wang, H.; Wang, Z.; He, S.; Chen, S.; Liao, D.; Wang, L.; Yan, J.; Liu, W.; Lei, X.; et al. Mixed lineage kinase domain-like protein mediates necrosis signaling downstream of RIP3 kinase. Cell 2012, 148, $213-227$. [CrossRef]

31. Zhan, S.-S.; Jiang, J.X.; Wu, J.; Halsted, C.; Friedman, S.L.; Zern, M.A.; Torok, N.J. Phagocytosis of apoptotic bodies by hepatic stellate cells induces NADPH oxidase and is associated with liver fibrosis in vivo. Hepatology 2006, 43, 435-443. [CrossRef] [PubMed]

32. Garcia-Martinez, I.; Santoro, N.; Chen, Y.; Hoque, R.; Ouyang, X.; Caprio, S.; Shlomchik, M.J.; Coffman, R.L.; Candia, A.; Mehal, W.Z. Hepatocyte mitochondrial DNA drives nonalcoholic steatohepatitis by activation of TLR9. J. Clin. Investig. 2016, 126, 859-864. [CrossRef] [PubMed]

33. Kono, H.; Chen, C.-J.; Ontiveros, F.; Rock, K.L. Uric acid promotes an acute inflammatory response to sterile cell death in mice. J. Clin. Investig. 2010, 120, 1939-1949. [CrossRef] [PubMed]

34. Gude, D.R.; Alvarez, S.E.; Paugh, S.W.; Mitra, P.; Yu, J.; Griffiths, R.; Barbour, S.E.; Milstien, S.; Spiegel, S. Apoptosis induces expression of sphingosine kinase 1 to release sphingosine-1-phosphate as a "come-and-get-me" signal. FASEB J. 2008, 22, 2629-2638. [CrossRef] [PubMed]

35. Hornung, V.; Bauernfeind, F.; Halle, A.; Samstad, E.O.; Kono, H.; Rock, K.L.; Fitzgerald, K.A.; Latz, E. Silica crystals and aluminum salts activate the NALP3 inflammasome through phagosomal destabilization. Nat. Immunol. 2008, 9, 847-856. [CrossRef] [PubMed]

36. Allam, R.; Kumar, S.V.R.; Darisipudi, M.N.; Anders, H.-J. Extracellular histones in tissue injury and inflammation. J. Mol. Med. (Berl.) 2014, 92, 465-472. [CrossRef]

37. Zhang, Q.; Raoof, M.; Chen, Y.; Sumi, Y.; Sursal, T.; Junger, W.; Brohi, K.; Itagaki, K.; Hauser, C.J. Circulating mitochondrial DAMPs cause inflammatory responses to injury. Nature 2010, 464, 104-107. [CrossRef]

38. Elliott, M.R.; Chekeni, F.B.; Trampont, P.C.; Lazarowski, E.R.; Kadl, A.; Walk, S.F.; Park, D.; Woodson, R.I.; Ostankovich, M.; Sharma, P.; et al. Nucleotides released by apoptotic cells act as a find-me signal to promote phagocytic clearance. Nature 2009, 461, 282-286. [CrossRef]

39. Ghiringhelli, F.; Apetoh, L.; Tesniere, A.; Aymeric, L.; Ma, Y.; Ortiz, C.; Vermaelen, K.; Panaretakis, T.; Mignot, G.; Ullrich, E.; et al. Activation of the NLRP3 inflammasome in dendritic cells induces IL-1beta-dependent adaptive immunity against tumors. Nat. Med. 2009, 15, 1170-1178. [CrossRef]

40. Ayata, C.K.; Ganal, S.C.; Hockenjos, B.; Willim, K.; Vieira, R.P.; Grimm, M.; Robaye, B.; Boeynaems, J.M.; Di

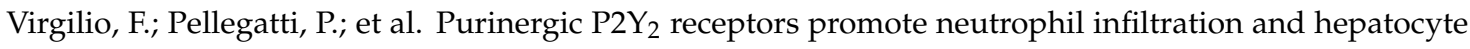
death in mice with acute liver injury. Gastroenterology 2012, 143, 1620-1629. [CrossRef]

41. Zhang, X.; Wu, X.; Hu, Q.; Wu, J.; Wang, G.; Hong, Z.; Ren, J. Lab for Trauma and Surgical Infections Mitochondrial DNA in liver inflammation and oxidative stress. Life Sci. 2019, 236, 116464. [CrossRef] [PubMed]

42. Xiao, F.; Waldrop, S.L.; Khimji, A.; Kilic, G. Pannexin1 contributes to pathophysiological ATP release in lipoapoptosis induced by saturated free fatty acids in liver cells. Am. J. Physiol. Cell Physiol. 2012, 303, C1034-C1044. [CrossRef] [PubMed]

43. Coddou, C.; Yan, Z.; Obsil, T.; Huidobro-Toro, J.P.; Stojilkovic, S.S. Activation and regulation of purinergic P2X receptor channels. Pharmacol. Rev. 2011, 63, 641-683. [CrossRef] [PubMed]

44. Romagnoli, R.; Baraldi, P.G.; Cruz-Lopez, O.; Lopez-Cara, C.; Preti, D.; Borea, P.A.; Gessi, S. The P2X7 receptor as a therapeutic target. Expert Opin. Ther. Targets 2008, 12, 647-661. [CrossRef] 
45. Di Virgilio, F. Liaisons dangereuses: P2X(7) and the inflammasome. Trends Pharmacol. Sci. 2007, 28 , 465-472. [CrossRef]

46. Andersson, U.; Tracey, K.J. HMGB1 is a therapeutic target for sterile inflammation and infection. Annu. Rev. Immunol. 2011, 29, 139-162. [CrossRef]

47. Tsung, A.; Klune, J.R.; Zhang, X.; Jeyabalan, G.; Cao, Z.; Peng, X.; Stolz, D.B.; Geller, D.A.; Rosengart, M.R.; Billiar, T.R. HMGB1 release induced by liver ischemia involves Toll-like receptor 4 dependent reactive oxygen species production and calcium-mediated signaling. J. Exp. Med. 2007, 204, 2913-2923. [CrossRef]

48. Zhou, R.-R.; Zhao, S.-S.; Zou, M.-X.; Zhang, P.; Zhang, B.-X.; Dai, X.-H.; Li, N.; Liu, H.-B.; Wang, H.; Fan, X.-G. HMGB1 cytoplasmic translocation in patients with acute liver failure. BMC Gastroenterol. 2011, 11, 21. [CrossRef]

49. Zhou, R.-R.; Liu, H.-B.; Peng, J.-P.; Huang, Y.; Li, N.; Xiao, M.-F.; Wang, H.; Fan, X.-G. High mobility group box chromosomal protein 1 in acute-on-chronic liver failure patients and mice with ConA-induced acute liver injury. Exp. Mol. Pathol. 2012, 93, 213-219. [CrossRef]

50. Chen, R.; Hou, W.; Zhang, Q.; Kang, R.; Fan, X.-G.; Tang, D. Emerging role of high-mobility group box 1 (HMGB1) in liver diseases. Mol. Med. 2013, 19, 357-366. [CrossRef]

51. Bianchi, M.E. HMGB1 loves company. J. Leukoc. Biol. 2009, 86, 573-576. [CrossRef] [PubMed]

52. Kao, Y.-H.; Jawan, B.; Goto, S.; Hung, C.-T.; Lin, Y.-C.; Nakano, T.; Hsu, L.-W.; Lai, C.-Y.; Tai, M.-H.; Chen, C.-L. High-mobility group box 1 protein activates hepatic stellate cells in vitro. Transplant. Proc. 2008, 40, 2704-2705. [CrossRef]

53. Ge, W.-S.; Wu, J.-X.; Fan, J.-G.; Wang, Y.-J.; Chen, Y.-W. Inhibition of high-mobility group box 1 expression by siRNA in rat hepatic stellate cells. World J. Gastroenterol. 2011, 17, 4090-4098. [CrossRef]

54. Zhang, Z.; Lin, C.; Peng, L.; Ouyang, Y.; Cao, Y.; Wang, J.; Friedman, S.L.; Guo, J. High mobility group box 1 activates Toll like receptor 4 signaling in hepatic stellate cells. Life Sci. 2012, 91, 207-212. [CrossRef]

55. Shi, Y.; Evans, J.E.; Rock, K.L. Molecular identification of a danger signal that alerts the immune system to dying cells. Nature 2003, 425, 516-521. [CrossRef]

56. Larsen, F.S.; Schmidt, L.E.; Bernsmeier, C.; Rasmussen, A.; Isoniemi, H.; Patel, V.C.; Triantafyllou, E.; Bernal, W.; Auzinger, G.; Shawcross, D.; et al. High-volume plasma exchange in patients with acute liver failure: An open randomised controlled trial. J. Hepatol. 2016, 64, 69-78. [CrossRef]

57. Xu, J.; Zhang, X.; Monestier, M.; Esmon, N.L.; Esmon, C.T. Extracellular histones are mediators of death through TLR2 and TLR4 in mouse fatal liver injury. J. Immunol. 2011, 187, 2626-2631. [CrossRef]

58. Yang, R.; Tonnesseen, T.I. DAMPs and sterile inflammation in drug hepatotoxicity. Hepatol. Int. 2019, 13, 42-50. [CrossRef]

59. Imaeda, A.B.; Watanabe, A.; Sohail, M.A.; Mahmood, S.; Mohamadnejad, M.; Sutterwala, F.S.; Flavell, R.A.; Mehal, W.Z. Acetaminophen-induced hepatotoxicity in mice is dependent on Tlr9 and the Nalp3 inflammasome. J. Clin. Investig. 2009, 119, 305-314. [CrossRef]

60. Watanabe, A.; Hashmi, A.; Gomes, D.A.; Town, T.; Badou, A.; Flavell, R.A.; Mehal, W.Z. Apoptotic hepatocyte DNA inhibits hepatic stellate cell chemotaxis via toll-like receptor 9. Hepatology 2007, 46, 1509-1518. [CrossRef]

61. Kroemer, G.; Galluzzi, L.; Kepp, O.; Zitvogel, L. Immunogenic cell death in cancer therapy. Annu. Rev. Immunol. 2013, 31, 51-72. [CrossRef] [PubMed]

62. Senovilla, L.; Vitale, I.; Martins, I.; Tailler, M.; Pailleret, C.; Michaud, M.; Galluzzi, L.; Adjemian, S.; Kepp, O.; Niso-Santano, M.; et al. An immunosurveillance mechanism controls cancer cell ploidy. Science 2012, 337, 1678-1684. [CrossRef] [PubMed]

63. Riddell, J.R.; Bshara, W.; Moser, M.T.; Spernyak, J.A.; Foster, B.A.; Gollnick, S.O. Peroxiredoxin 1 controls prostate cancer growth through Toll-like receptor 4-dependent regulation of tumor vasculature. Cancer Res. 2011, 71, 1637-1646. [CrossRef] [PubMed]

64. He, Y.; Li, S.; Tang, D.; Peng, Y.; Meng, J.; Peng, S.; Deng, Z.; Qiu, S.; Liao, X.; Chen, H.; et al. Circulating Peroxiredoxin-1 is a novel damage-associated molecular pattern and aggravates acute liver injury via promoting inflammation. Free Radic. Biol. Med. 2019, 137, 24-36. [CrossRef]

65. Riddell, J.R.; Wang, X.-Y.; Minderman, H.; Gollnick, S.O. Peroxiredoxin 1 stimulates secretion of proinflammatory cytokines by binding to TLR4. J. Immunol. 2010, 184, 1022-1030. [CrossRef]

66. Chen, G.-Y.; Tang, J.; Zheng, P.; Liu, Y. CD24 and Siglec-10 selectively repress tissue damage-induced immune responses. Science 2009, 323, 1722-1725. [CrossRef] 
67. Moussion, C.; Ortega, N.; Girard, J.-P. The IL-1-like cytokine IL-33 is constitutively expressed in the nucleus of endothelial cells and epithelial cells in vivo: A novel "alarmin"? PLoS ONE 2008, 3, e3331. [CrossRef]

68. Kouzaki, H.; Iijima, K.; Kobayashi, T.; O'Grady, S.M.; Kita, H. The danger signal, extracellular ATP, is a sensor for an airborne allergen and triggers IL-33 release and innate Th2-type responses. J. Immunol. 2011, 186, 4375-4387. [CrossRef]

69. Garg, A.D.; Krysko, D.V.; Vandenabeele, P.; Agostinis, P. Hypericin-based photodynamic therapy induces surface exposure of damage-associated molecular patterns like HSP70 and calreticulin. Cancer Immunol. Immunother. 2012, 61, 215-221. [CrossRef]

70. Spisek, R.; Charalambous, A.; Mazumder, A.; Vesole, D.H.; Jagannath, S.; Dhodapkar, M. V Bortezomib enhances dendritic cell (DC)-mediated induction of immunity to human myeloma via exposure of cell surface heat shock protein 90 on dying tumor cells: Therapeutic implications. Blood 2007, 109, 4839-4845. [CrossRef]

71. Li, P.; He, K.; Li, J.; Liu, Z.; Gong, J. The role of Kupffer cells in hepatic diseases. Mol. Immunol. 2017, 85, 222-229. [CrossRef] [PubMed]

72. Seki, E.; Tsutsui, H.; Nakano, H.; Tsuji, N.M.; Hoshino, K.; Adachi, O.; Adachi, K.; Futatsugi, S.; Kuida, K.; Takeuchi, O.; et al. Lipopolysaccharide-Induced IL-18 Secretion from Murine Kupffer Cells Independently of Myeloid Differentiation Factor 88 That Is Critically Involved in Induction of Production of IL-12 and IL-1 $\beta$. J. Immunol. 2001, 166, 2651-2657. [CrossRef] [PubMed]

73. Li, J.; Zhao, Y.-R.; Tian, Z. Roles of hepatic stellate cells in acute liver failure: From the perspective of inflammation and fibrosis. World J. Hepatol. 2019, 11, 412-420. [CrossRef] [PubMed]

74. Masola, V.; Carraro, A.; Granata, S.; Signorini, L.; Bellin, G.; Violi, P.; Lupo, A.; Tedeschi, U.; Onisto, M.; Gambaro, G.; et al. In vitro effects of interleukin (IL)-1 beta inhibition on the epithelial-to-mesenchymal transition (EMT) of renal tubular and hepatic stellate cells. J. Transl. Med. 2019, 17, 12. [CrossRef] [PubMed]

75. Kolios, G.; Valatas, V.; Kouroumalis, E. Role of Kupffer cells in the pathogenesis of liver disease. World J. Gastroenterol. 2006, 12, 7413-7420. [CrossRef]

76. Mosser, D.M.; Edwards, J.P. Exploring the full spectrum of macrophage activation. Nat. Rev. Immunol. 2008, 8, 958-969. [CrossRef]

77. Zhang, F.; Wang, H.; Wang, X.; Jiang, G.; Liu, H.; Zhang, G.; Wang, H.; Fang, R.; Bu, X.; Cai, S.; et al. TGF- $\beta$ induces M2-like macrophage polarization via SNAIL-mediated suppression of a pro-inflammatory phenotype. Oncotarget 2016, 7, 52294-52306. [CrossRef]

78. Koyama, Y.; Brenner, D.A. Liver inflammation and fibrosis. J. Clin. Investig. 2017, 127, 55-64. [CrossRef]

79. Gao, B.; Radaeva, S. Natural killer and natural killer T cells in liver fibrosis. Biochim. Biophys. Acta 2013, 1832, 1061-1069. [CrossRef]

80. Radaeva, S.; Wang, L.; Radaev, S.; Jeong, W.-I.; Park, O.; Gao, B. Retinoic acid signaling sensitizes hepatic stellate cells to NK cell killing via upregulation of NK cell activating ligand RAE1. Am. J. Physiol. Gastrointest. Liver Physiol. 2007, 293, G809-G816. [CrossRef]

81. Kurioka, A.; Walker, L.J.; Klenerman, P.; Willberg, C.B. MAIT cells: New guardians of the liver. Clin. Transl. Immunol. 2016, 5, e98. [CrossRef] [PubMed]

82. Hegde, P.; Weiss, E.; Paradis, V.; Wan, J.; Mabire, M.; Sukriti, S.; Rautou, P.-E.; Albuquerque, M.; Picq, O.; Gupta, A.C.; et al. Mucosal-associated invariant T cells are a profibrogenic immune cell population in the liver. Nat. Commun. 2018, 9, 2146. [CrossRef]

83. Aimaiti, Y.; Yusufukadier, M.; Li, W.; Tuerhongjiang, T.; Shadike, A.; Meiheriayi, A.; Gulisitan; Abudusalamu, A.; Wang, H.; Tuerganaili, A.; et al. TGF- $\beta 1$ signaling activates hepatic stellate cells through Notch pathway. Cytotechnology 2019, 71, 881-891. [CrossRef] [PubMed]

84. Fabregat, I.; Moreno-Càceres, J.; Sánchez, A.; Dooley, S.; Dewidar, B.; Giannelli, G.; ten Dijke, P. TGF- $\beta$ signalling and liver disease. FEBS J. 2016, 283, 2219-2232. [CrossRef] [PubMed]

85. Liu, X.; Hu, H.; Yin, J.Q. Therapeutic strategies against TGF-beta signaling pathway in hepatic fibrosis. Liver Int. 2006, 26, 8-22. [CrossRef]

86. Connolly, M.K.; Bedrosian, A.S.; Mallen-St Clair, J.; Mitchell, A.P.; Ibrahim, J.; Stroud, A.; Pachter, H.L.; Bar-Sagi, D.; Frey, A.B.; Miller, G. In liver fibrosis, dendritic cells govern hepatic inflammation in mice via TNF-alpha. J. Clin. Investig. 2009, 119, 3213-3225.

87. Saile, B.; Matthes, N.; El Armouche, H.; Neubauer, K.; Ramadori, G. The bcl, NFkappaB and p53/p21WAF1 systems are involved in spontaneous apoptosis and in the anti-apoptotic effect of TGF-beta or TNF-alpha on activated hepatic stellate cells. Eur. J. Cell Biol. 2001, 80, 554-561. [CrossRef] 
88. Schwabe, R.F.; Brenner, D.A. Mechanisms of Liver Injury. I. TNF-alpha-induced liver injury: Role of IKK, JNK and ROS pathways. Am. J. Physiol. Gastrointest. Liver Physiol. 2006, 290, G583-G589. [CrossRef]

89. Meng, F.; Wang, K.; Aoyama, T.; Grivennikov, S.I.; Paik, Y.; Scholten, D.; Cong, M.; Iwaisako, K.; Liu, X.; Zhang, M.; et al. Interleukin-17 signaling in inflammatory, Kupffer cells and hepatic stellate cells exacerbates liver fibrosis in mice. Gastroenterology 2012, 143, 765-776.e3. [CrossRef]

90. Gieling, R.G.; Wallace, K.; Han, Y.-P. Interleukin-1 participates in the progression from liver injury to fibrosis. Am. J. Physiol. Gastrointest. Liver Physiol. 2009, 296, G1324-G1331. [CrossRef]

91. Dinarello, C.A. Immunological and inflammatory functions of the interleukin-1 family. Annu. Rev. Immunol. 2009, 27, 519-550. [CrossRef] [PubMed]

92. Kamari, Y.; Shaish, A.; Vax, E.; Shemesh, S.; Kandel-Kfir, M.; Arbel, Y.; Olteanu, S.; Barshack, I.; Dotan, S.; Voronov, E.; et al. Lack of interleukin- $1 \alpha$ or interleukin- $1 \beta$ inhibits transformation of steatosis to steatohepatitis and liver fibrosis in hypercholesterolemic mice. J. Hepatol. 2011, 55, 1086-1094. [CrossRef] [PubMed]

93. Mehal, W.Z. The inflammasome in liver injury and non-alcoholic fatty liver disease. Dig. Dis. 2014, 32, 507-515. [CrossRef]

94. Miura, K.; Kodama, Y.; Inokuchi, S.; Schnabl, B.; Aoyama, T.; Ohnishi, H.; Olefsky, J.M.; Brenner, D.A.; Seki, E. Toll-like receptor 9 promotes steatohepatitis by induction of interleukin-1beta in mice. Gastroenterology 2010, 139, 323-334.e7. [CrossRef]

95. Molyvdas, A.; Georgopoulou, U.; Lazaridis, N.; Hytiroglou, P.; Dimitriadis, A.; Foka, P.; Vassiliadis, T.; Loli, G.; Phillipidis, A.; Zebekakis, P.; et al. The role of the NLRP3 inflammasome and the activation of IL-1 $\beta$ in the pathogenesis of chronic viral hepatic inflammation. Cytokine 2018, 110, 389-396. [CrossRef]

96. Zhang, Y.; Wang, Y.; Di, L.; Tang, N.; Ai, X.; Yao, X. Mechanism of interleukin-1 $\beta$-induced proliferation in rat hepatic stellate cells from different levels of signal transduction. APMIS 2014, 122, 392-398.

97. Huang, Y.-H.; Shi, M.-N.; Zheng, W.-D.; Zhang, L.-J.; Chen, Z.-X.; Wang, X.-Z. Therapeutic effect of interleukin-10 on CCl4-induced hepatic fibrosis in rats. World J. Gastroenterol. 2006, 12, 1386-1391. [CrossRef]

98. Huang, Y.-H.; Chen, M.-H.; Guo, Q.-L.; Chen, Y.-X.; Zhang, L.-J.; Chen, Z.-X.; Wang, X.-Z. Interleukin-10 promotes primary rat hepatic stellate cell senescence by upregulating the expression levels of p53 and p21. Mol. Med. Rep. 2018, 17, 5700-5707. [CrossRef]

99. Dudakov, J.A.; Hanash, A.M.; van den Brink, M.R.M. Interleukin-22: Immunobiology and pathology. Annu. Rev. Immunol. 2015, 33, 747-785. [CrossRef]

100. Wolk, K.; Witte, E.; Witte, K.; Warszawska, K.; Sabat, R. Biology of interleukin-22. Semin. Immunopathol. 2010, 32, 17-31. [CrossRef]

101. Carmo, R.F.; Cavalcanti, M.S.M.; Moura, P. Role of Interleukin-22 in chronic liver injury. Cytokine 2017, 98 , 107-114. [CrossRef] [PubMed]

102. Rutz, S.; Eidenschenk, C.; Ouyang, W. IL-22, not simply a Th17 cytokine. Immunol. Rev. 2013, 252, $116-132$. [CrossRef] [PubMed]

103. Radaeva, S.; Sun, R.; Pan, H.-N.; Hong, F.; Gao, B. Interleukin 22 (IL-22) plays a protective role in T cell-mediated murine hepatitis: IL-22 is a survival factor for hepatocytes via STAT3 activation. Hepatology 2004, 39, 1332-1342. [CrossRef] [PubMed]

104. Ki, S.H.; Park, O.; Zheng, M.; Morales-Ibanez, O.; Kolls, J.K.; Bataller, R.; Gao, B. Interleukin-22 treatment ameliorates alcoholic liver injury in a murine model of chronic-binge ethanol feeding: Role of signal transducer and activator of transcription 3. Hepatology 2010, 52, 1291-1300. [CrossRef] [PubMed]

105. Kong, X.; Feng, D.; Wang, H.; Hong, F.; Bertola, A.; Wang, F.-S.; Gao, B. Interleukin-22 induces hepatic stellate cell senescence and restricts liver fibrosis in mice. Hepatology 2012, 56, 1150-1159. [CrossRef] [PubMed]

106. Chen, E.; Cen, Y.; Lu, D.; Luo, W.; Jiang, H. IL-22 inactivates hepatic stellate cells via downregulation of the TGF- $31 /$ Notch signaling pathway. Mol. Med. Rep. 2018, 17, 5449-5453. [CrossRef]

107. Kishimoto, T. IL-6: From its discovery to clinical applications. Int. Immunol. 2010, 22, 347-352. [CrossRef]

108. Pradere, J.-P.; Kluwe, J.; De Minicis, S.; Jiao, J.-J.; Gwak, G.-Y.; Dapito, D.H.; Jang, M.-K.; Guenther, N.D.; Mederacke, I.; Friedman, R.; et al. Hepatic macrophages but not dendritic cells contribute to liver fibrosis by promoting the survival of activated hepatic stellate cells in mice. Hepatology 2013, 58, 1461-1473. [CrossRef]

109. He, G.; Karin, M. NF-кB and STAT3-key players in liver inflammation and cancer. Cell Res. 2011, 21, 159-168. [CrossRef] 
110. Xiang, D.-M.; Sun, W.; Ning, B.-F.; Zhou, T.-F.; Li, X.-F.; Zhong, W.; Cheng, Z.; Xia, M.-Y.; Wang, X.; Deng, X.; et al. The HLF/IL-6/STAT3 feedforward circuit drives hepatic stellate cell activation to promote liver fibrosis. Gut 2018, 67, 1704-1715. [CrossRef]

111. Farouk, S.; Sabet, S.; Abu Zahra, F.A.; El-Ghor, A.A. Bone marrow derived-mesenchymal stem cells downregulate IL17A dependent IL6/STAT3 signaling pathway in CC14-induced rat liver fibrosis. PLoS ONE 2018, 13, e0206130. [CrossRef]

112. Martinon, F.; Burns, K.; Tschopp, J. The inflammasome: A molecular platform triggering activation of inflammatory caspases and processing of proIL-beta. Mol. Cell 2002, 10, 417-426. [CrossRef]

113. Xiao, J.; Tipoe, G.L. Inflammasomes in non-alcoholic fatty liver disease. Front. Biosci. (Landmark. Ed.) 2016, 21, 683-695.

114. Rodrigue-Gervais, I.G.; Saleh, M. Caspases and immunity in a deadly grip. Trends Immunol. 2013, 34, 41-49. [CrossRef]

115. Ting, J.P.-Y.; Lovering, R.C.; Alnemri, E.S.; Bertin, J.; Boss, J.M.; Davis, B.K.; Flavell, R.A.; Girardin, S.E.; Godzik, A.; Harton, J.A.; et al. The NLR gene family: A standard nomenclature. Immunity 2008, 28, $285-287$. [CrossRef]

116. Boaru, S.G.; Borkham-Kamphorst, E.; Tihaa, L.; Haas, U.; Weiskirchen, R. Expression analysis of inflammasomes in experimental models of inflammatory and fibrotic liver disease. J. Inflamm. (Lond.) 2012, 9, 49. [CrossRef]

117. Chavarría-Smith, J.; Vance, R.E. The NLRP1 inflammasomes. Immunol. Rev. 2015, 265, 22-34. [CrossRef]

118. Liao, K.-C.; Mogridge, J. Activation of the Nlrp1b inflammasome by reduction of cytosolic ATP. Infect. Immun. 2013, 81, 570-579. [CrossRef]

119. Tanabe, T.; Chamaillard, M.; Ogura, Y.; Zhu, L.; Qiu, S.; Masumoto, J.; Ghosh, P.; Moran, A.; Predergast, M.M.; Tromp, G.; et al. Regulatory regions and critical residues of NOD2 involved in muramyl dipeptide recognition. EMBO J. 2004, 23, 1587-1597. [CrossRef]

120. Chen, T.T.W.; Cheng, P.C.; Chang, K.C.; Cao, J.P.; Feng, J.L.; Chen, C.C.; Lam, H.Y.P.; Peng, S.Y. Activation of the NLRP3 and AIM2 inflammasomes in a mouse model of Schistosoma mansoni infection. J. Helminthol. 2019, 94, e72. [CrossRef]

121. Rathinam, V.A.K.; Jiang, Z.; Waggoner, S.N.; Sharma, S.; Cole, L.E.; Waggoner, L.; Vanaja, S.K.; Monks, B.G.; Ganesan, S.; Latz, E.; et al. The AIM2 inflammasome is essential for host defense against cytosolic bacteria and DNA viruses. Nat. Immunol. 2010, 11, 395-402. [CrossRef]

122. Jones, J.W.; Kayagaki, N.; Broz, P.; Henry, T.; Newton, K.; O’Rourke, K.; Chan, S.; Dong, J.; Qu, Y.; Roose-Girma, M.; et al. Absent in melanoma 2 is required for innate immune recognition of Francisella tularensis. Proc. Natl. Acad. Sci. USA 2010, 107, 9771-9776. [CrossRef]

123. Han, Y.; Chen, Z.; Hou, R.; Yan, D.; Liu, C.; Chen, S.; Li, X.; Du, W. Expression of AIM2 is correlated with increased inflammation in chronic hepatitis B patients. Virol. J. 2015, 12, 129. [CrossRef]

124. Benetti, E.; Chiazza, F.; Patel, N.S.A.; Collino, M. The NLRP3 Inflammasome as a novel player of the intercellular crosstalk in metabolic disorders. Mediat. Inflamm. 2013, 2013, 678627. [CrossRef]

125. Inzaugarat, M.E.; Johnson, C.D.; Holtmann, T.M.; McGeough, M.D.; Trautwein, C.; Papouchado, B.G.; Schwabe, R.; Hoffman, H.M.; Wree, A.; Feldstein, A.E. NLR Family Pyrin Domain-Containing 3 Inflammasome Activation in Hepatic Stellate Cells Induces Liver Fibrosis in Mice. Hepatology 2019, 69, 845-859. [CrossRef]

126. Luan, J.; Ju, D. Inflammasome: A Double-Edged Sword in Liver Diseases. Front. Immunol. 2018, 9, 2201. [CrossRef]

127. Wree, A.; McGeough, M.D.; Peña, C.A.; Schlattjan, M.; Li, H.; Inzaugarat, M.E.; Messer, K.; Canbay, A.; Hoffman, H.M.; Feldstein, A.E. NLRP3 inflammasome activation is required for fibrosis development in NAFLD. J. Mol. Med. 2014, 92, 1069-1082. [CrossRef]

128. Szabo, G.; Iracheta-Vellve, A. Inflammasome activation in the liver: Focus on alcoholic and non-alcoholic steatohepatitis. Clin. Res. Hepatol. Gastroenterol. 2015, 39 (Suppl. 1), S18-S23. [CrossRef]

129. Weiskirchen, R.; Tacke, F. Cellular and molecular functions of hepatic stellate cells in inflammatory responses and liver immunology. Hepatobiliary Surg. Nutr. 2014, 3, 344-363.

130. Watanabe, A.; Sohail, M.A.; Gomes, D.A.; Hashmi, A.; Nagata, J.; Sutterwala, F.S.; Mahmood, S.; Jhandier, M.N.; Shi, Y.; Flavell, R.A.; et al. Inflammasome-mediated regulation of hepatic stellate cells. Am. J. Physiol. Liver Physiol. 2009, 296, G1248-G1257. [CrossRef] 
131. Ouyang, X.; Ghani, A.; Mehal, W.Z. Inflammasome biology in fibrogenesis. Biochim. Biophys. Acta 2013, 1832, 979-988. [CrossRef]

132. Dostert, C.; Pétrilli, V.; Van Bruggen, R.; Steele, C.; Mossman, B.T.; Tschopp, J. Innate immune activation through Nalp3 inflammasome sensing of asbestos and silica. Science 2008, 320, 674-677. [CrossRef]

133. Kubes, P.; Mehal, W.Z. Sterile inflammation in the liver. Gastroenterology 2012, 143, 1158-1172. [CrossRef]

134. Murakami, T.; Ockinger, J.; Yu, J.; Byles, V.; McColl, A.; Hofer, A.M.; Horng, T. Critical role for calcium mobilization in activation of the NLRP3 inflammasome. Proc. Natl. Acad. Sci. USA 2012, 109, 11282-11287. [CrossRef]

135. Lee, G.-S.; Subramanian, N.; Kim, A.I.; Aksentijevich, I.; Goldbach-Mansky, R.; Sacks, D.B.; Germain, R.N.; Kastner, D.L.; Chae, J.J. The calcium-sensing receptor regulates the NLRP3 inflammasome through Ca2+ and cAMP. Nature 2012, 492, 123-127. [CrossRef]

136. Compan, V.; Baroja-Mazo, A.; López-Castejón, G.; Gomez, A.I.; Martínez, C.M.; Angosto, D.; Montero, M.T.; Herranz, A.S.; Bazán, E.; Reimers, D.; et al. Cell volume regulation modulates NLRP3 inflammasome activation. Immunity 2012, 37, 487-500. [CrossRef]

137. Zhong, Z.; Zhai, Y.; Liang, S.; Mori, Y.; Han, R.; Sutterwala, F.S.; Qiao, L. TRPM2 links oxidative stress to NLRP3 inflammasome activation. Nat. Commun. 2013, 4, 1611. [CrossRef]

138. Lerner, A.G.; Upton, J.-P.; Praveen, P.V.K.; Ghosh, R.; Nakagawa, Y.; Igbaria, A.; Shen, S.; Nguyen, V.; Backes, B.J.; Heiman, M.; et al. IRE1 $\alpha$ induces thioredoxin-interacting protein to activate the NLRP3 inflammasome and promote programmed cell death under irremediable ER stress. Cell Metab. 2012, 16, 250-264. [CrossRef]

139. Oslowski, C.M.; Hara, T.; O’Sullivan-Murphy, B.; Kanekura, K.; Lu, S.; Hara, M.; Ishigaki, S.; Zhu, L.J.; Hayashi, E.; Hui, S.T.; et al. Thioredoxin-interacting protein mediates ER stress-induced $\beta$ cell death through initiation of the inflammasome. Cell Metab. 2012, 16, 265-273. [CrossRef]

140. Xiao, J.; Zhu, Y.; Liu, Y.; Tipoe, G.L.; Xing, F.; So, K.-F. Lycium barbarum polysaccharide attenuates alcoholic cellular injury through TXNIP-NLRP3 inflammasome pathway. Int. J. Biol. Macromol. 2014, 69, 73-78. [CrossRef]

141. de Torre-Minguela, C.; Barberà-Cremades, M.; Gómez, A.I.; Martín-Sánchez, F.; Pelegrín, P. Macrophage activation and polarization modify P2X7 receptor secretome influencing the inflammatory process. Sci. Rep. 2016, 6, 22586. [CrossRef]

142. Keller, M.; Rüegg, A.; Werner, S.; Beer, H.-D. Active caspase-1 is a regulator of unconventional protein secretion. Cell 2008, 132, 818-831. [CrossRef]

143. Gross, O.; Yazdi, A.S.; Thomas, C.J.; Masin, M.; Heinz, L.X.; Guarda, G.; Quadroni, M.; Drexler, S.K.; Tschopp, J. Inflammasome activators induce interleukin- $1 \alpha$ secretion via distinct pathways with differential requirement for the protease function of caspase-1. Immunity 2012, 36, 388-400. [CrossRef]

144. Yang, D.; Postnikov, Y.V.; Li, Y.; Tewary, P.; de la Rosa, G.; Wei, F.; Klinman, D.; Gioannini, T.; Weiss, J.P.; Furusawa, T.; et al. High-mobility group nucleosome-binding protein 1 acts as an alarmin and is critical for lipopolysaccharide-induced immune responses. J. Exp. Med. 2012, 209, 157-171. [CrossRef]

145. Haneklaus, M.; O'Neill, L.A.J.; Coll, R.C. Modulatory mechanisms controlling the NLRP3 inflammasome in inflammation: Recent developments. Curr. Opin. Immunol. 2013, 25, 40-45. [CrossRef]

146. Miao, E.A.; Rajan, J.V.; Aderem, A. Caspase-1-induced pyroptotic cell death. Immunol. Rev. 2011, 243, 206-214. [CrossRef]

147. Orning, P.; Weng, D.; Starheim, K.; Ratner, D.; Best, Z.; Lee, B.; Brooks, A.; Xia, S.; Wu, H.; Kelliher, M.A.; et al. Pathogen blockade of TAK1 triggers caspase-8-dependent cleavage of gasdermin D and cell death. Science 2018, 362, 1064-1069. [CrossRef]

148. Aglietti, R.A.; Dueber, E.C. Recent Insights into the Molecular Mechanisms Underlying Pyroptosis and Gasdermin Family Functions. Trends Immunol. 2017, 38, 261-271. [CrossRef]

149. Wu, J.; Lin, S.; Wan, B.; Velani, B.; Zhu, Y. Pyroptosis in Liver Disease: New Insights into Disease Mechanisms. Aging Dis. 2019, 10, 1094. [CrossRef]

150. Kayagaki, N.; Stowe, I.B.; Lee, B.L.; O’Rourke, K.; Anderson, K.; Warming, S.; Cuellar, T.; Haley, B.; Roose-Girma, M.; Phung, Q.T.; et al. Caspase-11 cleaves gasdermin D for non-canonical inflammasome signalling. Nature 2015, 526, 666-671. [CrossRef]

151. Shi, J.; Zhao, Y.; Wang, K.; Shi, X.; Wang, Y.; Huang, H.; Zhuang, Y.; Cai, T.; Wang, F.; Shao, F. Cleavage of GSDMD by inflammatory caspases determines pyroptotic cell death. Nature 2015, 526, 660-665. [CrossRef] 
152. Franchi, L.; Eigenbrod, T.; Muñoz-Planillo, R.; Nuñez, G. The inflammasome: A caspase-1-activation platform that regulates immune responses and disease pathogenesis. Nat. Immunol. 2009, 10, 241-247. [CrossRef]

153. Mirshafiee, V.; Sun, B.; Chang, C.H.; Liao, Y.-P.; Jiang, W.; Jiang, J.; Liu, X.; Wang, X.; Xia, T.; Nel, A.E. Toxicological Profiling of Metal Oxide Nanoparticles in Liver Context Reveals Pyroptosis in Kupffer Cells and Macrophages versus Apoptosis in Hepatocytes. ACS Nano 2018, 12, 3836-3852. [CrossRef]

154. Pan, J.; Ou, Z.; Cai, C.; Li, P.; Gong, J.; Ruan, X.Z.; He, K. Fatty acid activates NLRP3 inflammasomes in mouse Kupffer cells through mitochondrial DNA release. Cell. Immunol. 2018, 332, 111-120. [CrossRef]

155. Lebeaupin, C.; Proics, E.; de Bieville, C.H.D.; Rousseau, D.; Bonnafous, S.; Patouraux, S.; Adam, G.; Lavallard, V.J.; Rovere, C.; Le Thuc, O.; et al. ER stress induces NLRP3 inflammasome activation and hepatocyte death. Cell Death Dis. 2015, 6, e1879. [CrossRef]

156. Heo, M.J.; Kim, T.H.; You, J.S.; Blaya, D.; Sancho-Bru, P.; Kim, S.G. Alcohol dysregulates miR-148a in hepatocytes through FoxO1, facilitating pyroptosis via TXNIP overexpression. Gut 2019, 68, 708-720. [CrossRef]

157. Petrasek, J.; Iracheta-Vellve, A.; Saha, B.; Satishchandran, A.; Kodys, K.; Fitzgerald, K.A.; Kurt-Jones, E.A.; Szabo, G. Metabolic danger signals, uric acid and ATP, mediate inflammatory cross-talk between hepatocytes and immune cells in alcoholic liver disease. J. Leukoc. Biol. 2015, 98, 249-256. [CrossRef]

158. Luan, J.; Zhang, X.; Wang, S.; Li, Y.; Fan, J.; Chen, W.; Zai, W.; Wang, S.; Wang, Y.; Chen, M.; et al. NOD-Like Receptor Protein 3 Inflammasome-Dependent IL-1ß Accelerated ConA-Induced Hepatitis. Front. Immunol. 2018, 9, 758. [CrossRef]

159. Kofahi, H.M.; Taylor, N.G.A.; Hirasawa, K.; Grant, M.D.; Russell, R.S. Hepatitis C Virus Infection of Cultured Human Hepatoma Cells Causes Apoptosis and Pyroptosis in Both Infected and Bystander Cells. Sci. Rep. 2016, 6, 37433. [CrossRef]

160. Beier, J.I.; Banales, J.M. Pyroptosis: An inflammatory link between NAFLD and NASH with potential therapeutic implications. J. Hepatol. 2018, 68, 643-645. [CrossRef]

161. Henao-Mejia, J.; Elinav, E.; Jin, C.; Hao, L.; Mehal, W.Z.; Strowig, T.; Thaiss, C.A.; Kau, A.L.; Eisenbarth, S.C.; Jurczak, M.J.; et al. Inflammasome-mediated dysbiosis regulates progression of NAFLD and obesity. Nature 2012, 482, 179-185. [CrossRef]

162. Khanova, E.; Wu, R.; Wang, W.; Yan, R.; Chen, Y.; French, S.W.; Llorente, C.; Pan, S.Q.; Yang, Q.; Li, Y.; et al. Pyroptosis by caspase11/4-gasdermin-D pathway in alcoholic hepatitis in mice and patients. Hepatology 2018, 67, 1737-1753. [CrossRef] 